\title{
Publikationsetik - om at formidle videnskab forståeligt og troværdigt
}

\author{
At skrive forståeligt og troværdigt om videnskab, hvad enten det baseres på egne undersøgelser \\ eller andres resultater, stiller mere end rent tekniske krav. Læsernes forventning til fremstil- \\ lingens pålidelighed er meget store, helt til selvfølgeligheden. Og hermed er vi på publikations- \\ etikkens område, som i denne kronik tager udgangspunkt i alle målgrupper i et projekts lange \\ vej fra idé til publicerede konklusioner.
}

Basert på et foredrag på møtet for Tidsskriftets faglige medarbeidere på Vettre 18.3. 2010.

Povl Riis

aha@aeldreforum.dk

Nerievej 7

DK-2900 Hellerup

Overbegrebet publikationsetik rummer to sammenkoblede termer. Det første, publikationen, er det sidste tekniske led i den videnskabsetiske sammenhængskæde, fra den originale idé, over metodologien som den grundlæggende værktøjsteknik, sandhedsog fortolkningsaspektet, som er beregnet til målgrupperne: de professionelle og de nuværende og fremtidige patienter. Den sidste del af titlens overbegreb, etikken, ledsager ideelt det videnskabelige projekt fra begyndelsen til afslutningen, hvoraf afslutningen er afgørende for ikke blot national og international udbredelse af netværket, men også som den metaforiske møntfod for forskerverdenens meritering og c.v.-dokumentationer.

Svarende til publikationsetikkens logistiske fleksibilitet er de berørte grupper af aktører og interessenter også adskillige, nemlig projektdeltagende forskere, potentielle brugere i klinisk diagnostik, behandlinger og forebyggelse, patienter med behandlings- og forebyggelsesinteresser, sundhedspolitikere og - økonomer, samt redaktører, eksterne fagkonsulenter, og ikke mindst den store gruppe læsere. Og før emnet perspektiveres inden for hver af disse grupper, bør termen etik betydningsmæssigt afgrænses i definitionsform.

\section{Definitionen på etik}

Etikken søges ofte defineret etymologisk, dvs. ud fra læren om ords og begrebers oprindelse, fx på formen «stammer fra græsk og betyder det gode liv». Afstanden fra det gamle Hellas' filosoffer og deres samfundssociale menneskesyn er imidlertid alt for stor til, at en etymologisk definition kan anven- des i nutidig, sundhedsfaglig forskning. Derfor må semantikken, dvs. læren om ords og begrebers nutidige betydning anvendes i stedet for, hvilket ikke er sket hyppigt (om overhovedet). Dette dilemma har jeg for flere år siden søgt at løse ved udformning af min egen definition, som er anvendt hyppigt nationalt og internationalt (1), da den også bør have en global spændvidde om muligt, eller i det mindste en høj grad af transkulturel gennemskuelighed. Her gengives den dansksprogede version:

«Etik er et overordnet begreb for de ikkematerielle værdier, normer og holdninger, som er grundlæggende i et lands og/eller en kultur's menneskesyn, de heraf afledte nationale love og andre regelsæt, og som herudfra er ideelt bestemmende for borgernes personlige livsvilkår og adfærd, for deres liv indbyrdes, og for forholdet til samfundets officielle og private institutioner.

I et globalt perspektiv omfatter etikkens ikke-materielle værdier også et ansvar for planeten Jordens økologiske balance, dens jord, vand og luft, samt dens floras \& faunas bevarede diversitet».

De vigtigste af de oven for nævnte ikkematerielle værdier i den semantiske etikdefinition er følgende:

- Medmenneskelighed(solidaritet i forhold til medborgerne)

- Menneskeligt ligeværd

- Sandhed

- Retfærdighed

- Ansvarlighed

- Frihed

- Professionalisme

I sammenhænge uden for videnskabsetikken, fx i generelle samværskontakter, samt i servicekontakter, indgår også humor i gruppen af ikke-materielle, grundlæggende værdier (hvor humor anses for en af de væsentligste livsytringer, som signalerer ligeværd inden for menneskehedens store fællesskab af skrøbelighed).

\section{De historiske lange rødder}

Først skal omtales traditionen for at lære af historiens - her videnskabshistoriens beskrivelse af fejl og fremskridt, på den lange vej til evidens som nødvendigt grundlag for kliniske og epidemiologiske beslutninger på patient- og samfundsniveau. Her skal vi helt tilbage til det klassiske Hellas, til historikeren Thukydid (466-400 f.K.), som skabte det stadigt gyldige udsagn, «at hvis vi ikke kender historien, er vi dømt til at gentage dens fejltagelser» (P.R.: «at tage afsæt i dens beskrevne mulige konstruktive ideer» bør inkluderes).

Vejen til sundhedsfaglig evidens rummer navne som bl.a. James Lind (1716-94), engelsk marinelæge, som skabte den kontrollerede undersøgelse af citronsaft som skørbug-forebyggelse i 1753, ved sammenligning af 5 forskellige formodede behandlinger over for en kontrolgruppe, hos engelske søfolk på langfart (2).

Nævnes skal også Claude Bernard (1813-78), den franske fysiologforsker, som regnes for en af metodologiens fædre, især på området som i dag kaldes translationel forskning, dvs. vejen fra laboratorieforsøg til klinisk forskning (2).

En større kontrolleret undersøgelse foretog Johannes Fibiger (1867-1928) over et år, med publikation i 1897 af en undersøgelse af serumbehandling af difteri, og beskrev en markant effekt (2).

Statistikken som forskningsværktøj indførtes af Karl Pearson (1857-1936) og Ronald Fisher (1890-1962) i begyndelsen af 1900-tallet.

Meget stor indflydelse på den kliniskkontrollerede undersøgelse som metode fik Austin Bradford Hill (1896-1991), som gennem en række publikationer i metodologi, dvs. læren om det evidensskabende forsøgs teori og valg af sammenligningsgrundlag. Hans epokegørende praktiske anvendelse af metodologien var hans lederskab bag den store engelske kontrol- 


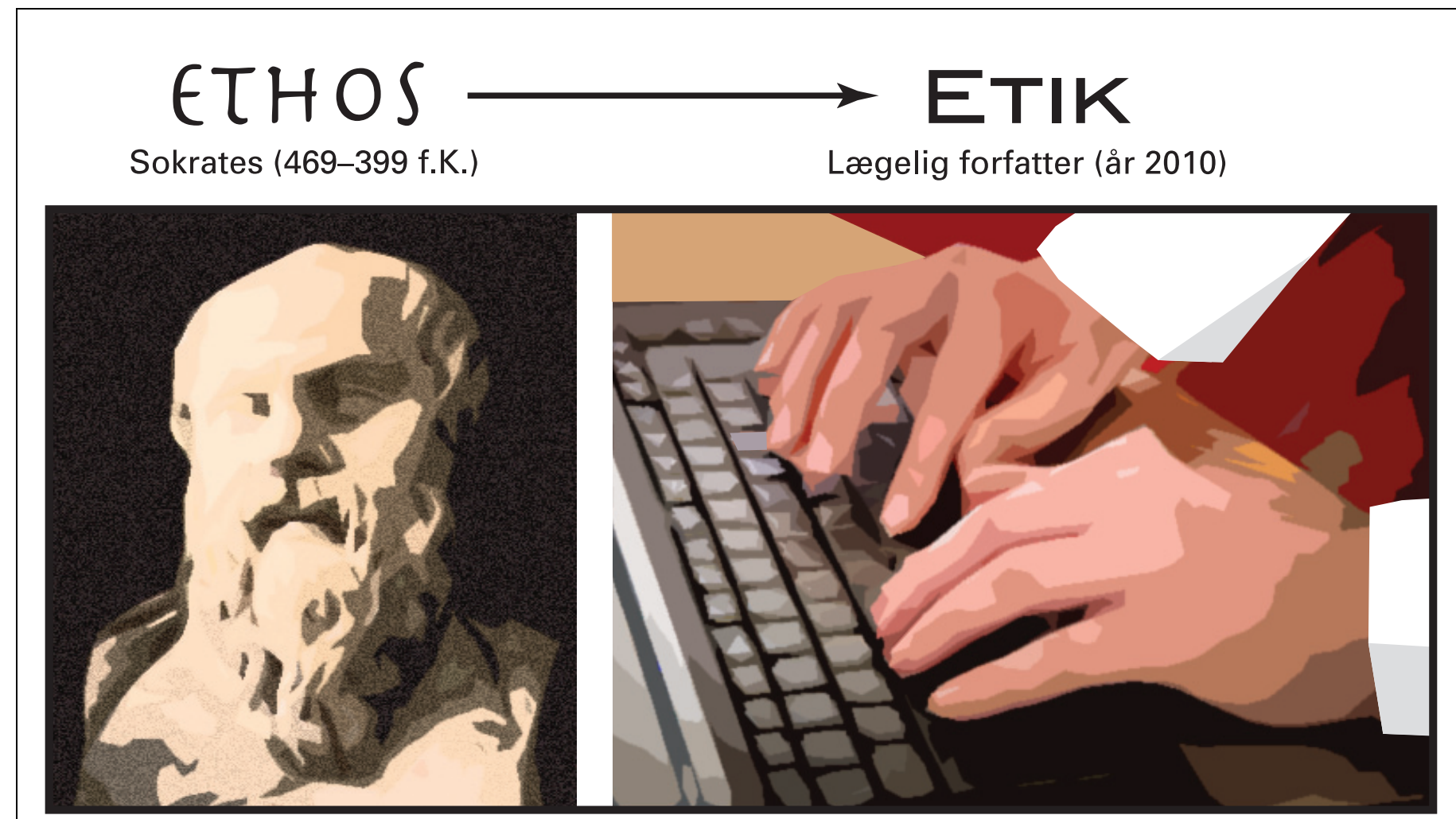

Etikbegrebets historisk-etymologiske spændvidde

lerede undersøgelse af streptomycins virkning på lungetuberkulose fra 1948

(3).

Etikkens andel af videnskabsetikken skabtes paradoksalt ikke med udgang i den oprindelige, græske betydning, «det gode liv», men tragisk nok ved en opdukken af behovet for etikken ud fra menneskeskabte former af «det onde liv» $\mathrm{i}$ japanske og tyske koncentrationslejre, og senere i USSR's

Gulaglejre. Her gennemførtes forsøg, inklusive medicinske, på fanger, uden information, samtykke, eller risikovurderinger. Gennem efterkrigstidens afsløringer og retssager mod de ansvarlige skabtes grundlaget for Genevedeklarationen, og de opfølgende Helsinkideklarationer, samt Europarådets Bioetikkonvention fra Oviedo 1997. Til disse vigtige gen- $\&$ nyskabelser af sundhedsvidenskabernes etiske regelsæt har Nordens medicinske forskere ydet væsentlige bidrag, i de seneste årtier også ved at inddrage publikationsetikken samt forskernes personlige etik (videnskabelige redelighed, i modsætning til $u$ redelighed) (4).

\section{Etisk adfærd fra idé til publikation}

Forskerambitioner og praktiske veje til en original projektidé

De retmæssige forventninger og idealer er her den originale idé, skabt ved egne observationer i laboratoriet, ved sygesengen, eller ved sammenlignende kildekritisk læsning af de globale publikationer, som rummer den eksisterende evidens på et forskningsfelt. Uretmæssigt forekommer fabrikation af grundlaget for ideer, idétyveri fra konferencer, eller funktion som vejleder eller ekstern fagkonsulent. Resultaterne er en belastning af publikationsetikken, om end den er vanskelig at afsløre af redaktioner og i blandt også af kyndige og ærlige eksterne fagkonsulenter.

\section{Det praktiske projektarbejde og} metodologien som dets «værktøjskasse» I denne projektfase sker de fleste overtrædelser af videnskabs- og publikationsetikkens troværdighed $(5,6)$. Her forekommer «fabrikation» af forskningsdata og forfalskning af erhvervede data, som har skuffet forskerens forventninger, og signifikansprøvernes eventuelle ubarmhjertighed. Men også tyveri af andres forskeres publicerede eller IT-tilgængelige data forekommer. Også her er uredeligheden vanskelig for redaktionerne at gennemskue, hvis rådata ikke er tilgængelige, lidt lettere er det for en statistisk konsulent ved eventuel forekomst af usandsynlige cifferfordelinger skabt ved datafabrikation.

\section{Fortolkning af resultaterne}

og disses perspektivering

Idealet er her, at alle resultater er sande, og at ingen data er fjernet, fordi de er «udeliggere» $\mathrm{i}$ forhold til hovedparten, og derfor skaber høje p-værdier og lave r-værdier. Perspektivering omfatter en dækkende omtale af foreliggende, evidensskabende eller -udelukkende resultater fra den globale litteratur, for på falsk grundlag at øge den personlige meritering. En meget værdifuld forøgelse af et manuskripts publikationsetiske kvalitet kan opnås, hvis redaktioner fordrer, at alle forfattere i manuskriptets diskussionsafsnit indføjer et afsnit om undersøgelsens svagheder $i$ et evidensperspektiv.

\section{Den valgte publiceringsform og forfatterbegrebet}

Videnskabelige projekter bør etisk set indgå i videnskabeligt redigeret publikationer, hvad enten de har en trykt eller skærmskabt form, og forudsat at kun ét sted ad gangen tentativt modtager det. Forfatterdefinitionen og dens overholdelse er stadig et internationalt svagt punkt i publiseringsetikken, trods en intensiv indsats fra ICMJE's (Vancouvergruppen) side. Personligt er jeg på dette punkt endt med at styrke kontrol og tilgængelighed på følgende måde: Ved fremsendelse af et manuskript skal alle angivne forfatteres indsats beskrives på separate, personlige ark, som med alles underskrift på hvert ark fungerer som bilag, som udtryk for forfatternes fælles accept. De bør tillige arkiveres i forskningsinstitutionen, hvorfra projektet koordineres og styres. Tidsskriftet, eller forlaget, bør udforme en checkliste til dette formål. Ved fonds- og stillingsansøgninger, samt ved bedømmelse af disputats- og ph.d.-afhandlinger, skal 
ansøgeres indsats, $\mathrm{i}$ det mindste inden for et vist antal af ansøgningens kernepublikationer (fx 10) ledsages af de eksisterende forfatterdokumentationer. På denne måde vanskeliggøres såkaldte «forfatterkollektivers» funktion (skabt ud fra «Hvis jeg er medforfatter på dine publikationer, har du samme adgang til mine»).

\section{Redaktørers og eksterne fagkonsulenters} etiske udfordringer

Redaktører besidder en vis magt over forfatteres faglige liv og c.v.'er som afspejling af deres kvalifikationer. Det kræver habilitet og åbenhed, som i øvrigt fremmes pga. redaktioners navneindifikationer og korrespondancespalters tilgængelighed. Vanskeligere er det at sikre eksterne fagkonsulenters habilitet i tidsskrifter og forlag, hvor bedømmerne er anonymiseret. Da eksterne fagkonsulenter skal have faglig indsigt, kan de derfor befinde sig i en konkurrencesituation i forhold til forfatteren(-ne). Når man selv har oplevet, at en Verdensoriginal opfindelse, sendt til globalt førende tidsskrift, blev forsinket af en bedømmer, så længe at han kunne nå at foretage en totalt efterlignende undersøgelse, og dermed kunne køre dødt løb med de to forfattere (og senere indrømmede det), har man mistet illusionen om det eksterne fagkonsulentsystemets iboende uskyld.

Læsernes etisk begrundede behov for publikationsetikkens kvalitetskrav Som sidste målgruppe må læserne indlysende ikke glemmes, fordi de med rette stoler på, at den færdige publikation har opfyldt de nødvendige kvalitetskrav under projektets vej fra idé til publikation. Her ligger de kvalitetsbevidste og -respekterendes tidsskrifters store informationsværdi i forhold til de uredigerede IT-kilder, og de øvrige medier, der heller ikke altid benytter sig af kildekritisk brug ved videnskabeligt stof.

Uddannelses-, forebyggelses-og

kontrolperspektiver for kommende forskere

Publikationsetikken bør, sammen med videnskabsetikken (research ethics) og forskeretikken (researcher's ethics), i et fremtidsperspektiv indgå i undervisningen inden for sundhedsfagene, have en fast og eksplicit plads i institutionskulturen, samt have tilhørsforhold til et - helt uafhængigt statsligt - organ, som med juridisk bistand har til opgave at varetage undersøgelser af mistænkte grove brud på publikationsetikken.

For uddannelsesperspektivet er kursusmoduler for unge forskere meget nyttige, og i institutionerne er de begyndende erfaringer med institutionschefers og afdelingslederes deltagelse, støttet af en lokal ombudsmandsfunktion meget positive.

Chefers og vejlederes positive rollemodeller, $\mathrm{fx}$ ved at besidde et ubestikkeligt forhold til en nødvendig uoverensstemmelse imellem chef- og vejlederfunktioner på den ene side, og uspecificerede medforfatterskaber på den anden, har stor betydning for en institutions etiske klima.

Det samme gælder den anden ende af nutidige og fremtidige forskeres aldersspektrum. Hvis unge forskere i deres skoletid fx har erfaret, at løsning af en matematikopgave eller en formulering af personlige stile (essays) er en accepteret indsats, selv om der er tale om ren afskrift af en andens tidligere arbejde, og er ukommenteret fra hjem og måske skole, vil videnskabelig uredelighed, samt et selvcentreret syn på forsøgspatienter, udgøre en eksistentiel hæmning af etikkens nødvendighed $i$ et globaliseret forskningsunivers.

Oppgitte interessekonflikter: Ingen

\section{Litteratur}

1. Riis P. History and definitions. Kapitel 2. I: Ethical eye: biomedical research. Strasbourg: Council of Europe Publishing, 2004: 19-31.

2. Gotfredsen E. Medicinens historie. 2. udg. København: Ny Nordisk Forlag Arnold Busck, 1964.

3. Streptomycin in Tuberculosis Trial Committee. Streptomycin treatment of pulmonary tuberculosis. BMJ 1948; 2: 769-82. www.ncbi.nlm.nih.gov/ pmc/articles/PMC2091872 (17.5.2010).

4. Andersen D, Attrup L, Axelsen $\mathrm{N}$ et al. Scientific dishonesty and good scientific practice. København: Danish Medical Research Council, 1992; 19-22.

5. Riis P. The concept of scientific dishonesty: ethics value systems and research. Kap. 1. I: Wells F, Farthing $M$, red. Fraud and misconduct in biomedical research. 4. udg. London: Royal Society of Medicine Press, 2008.

6. Benestad HB. Vitenskapelig uredelighet - alvorlig, forsettlig eller grovt uaktsomt? Tidsskr Nor Legeforen 2010; 130: 515-6.

Manuskriptet ble mottatt 10.5. 2010 og godkjent 20.5. 2010. Medisinsk redaktør Erlend Hem. 